\title{
Application of an Educational Program on Lifestyle of Perimenopausal Women Utilizing PRECEDE - PROCEED Model
}

\section{Gehad Gamal El-Said ${ }^{1}$, Moharam Abdelhaseeb ${ }^{2}$, Soad Abdel-Salam Ramadan ${ }^{3}$, and Samah Abdel-Haliem Said ${ }^{4}$}

(1) Assistant Instructor of Obstetrics and Woman's Health Nursing, Faculty of Nursing - Benha University, (2) Professor of Obstetrics and Gynecology, Faculty of Medicine, Benha University, (3) Professor of Obstetrics and Gynecological Nursing, Faculty of Nursing, Benha University and (4) Assistant Professor of Obstetrics and Woman's Health Nursing, Faculty of Nursing Benha University

\begin{abstract}
Background: Perimenopause represents a critical life stage encompassing a range of physiological and psychosocial changes that require a healthy lifestyle to promote health and functioning. Aim: The study aimed to investigate the effect of an educational program on lifestyle of perimenopausal women utilizing PRECEDE-PROCEED model. Design: Quasi-experimental (study-control / time series) study was utilized. Setting: Administrative building of Benha university hospitals. Sample: A purposive sample of (109 women) was selected according to inclusion and exclusion criteria. The sample consisted of two groups (study group comprised (55) perimenopausal women who received the program and control group comprised (54) perimenopausal women who didn't not receive the program). Tools of data collection: A structured interviewing questionnaire sheet, and health-promoting lifestyle profile. Results: After three and six months of program application, the mean scores of predisposing factors, reinforcing factors, enabling factors and health promoting lifestyle of the study group were significantly higher than the scores in the control group $(\mathrm{P}<0.001)$. Conclusion: PRECEDE - PROCEED model provided an excellent framework for health intervention programs and improved the understanding of the relationship among health-promoting lifestyle, educational and ecological assessment phase structures and demographic factors. Recommendation: Implementing an educational intervention based on PRECEDE - PROCEED model on women's lifestyle at different stages of life and settings especially workplaces with high female density.
\end{abstract}

Key words: Educational program, Lifestyle, Perimenopausal women, PRECEDES - PRECEDE model.

\section{Introduction:}

Women's health at different age groups is an important issue to reach the efficiency to perform all duties according to responsibilities and to increase the productive capacity which will consequently promote the national economy. One of these health problems affecting women is the period of peri-menopause which can influence the personal satisfaction and well-being (Falkingham et al., 2020).
Peri-menopause represents a delicate transition period of a woman's life during which physiological, affective, psychological, and social changes mark progression from a woman's fertile life to climaterium, with wide sexual hormones fluctuations until the onset of hypergonadotropic amenorrhea. During this stage, because of the decreases or fluctuations of sex hormones caused by recession of ovarian function, women undergo a series of psychological and 
physical symptoms, clinically called perimenopausal syndrome (Huang, et al., 2020).

There has been increasing interest in non-hormonal and non-medication-based approaches to managing peri-menopausal symptoms and optimizing post-reproductive health. Lifestyle which is non-hormonal management of perimenopausal symptoms may be a new choice for women with mild to moderate perimenopausal syndrome (Marshall and Rees, 2020).

Health-promoting lifestyle (HPL) helps individuals to take control of, maintain, and enhance health. As a kind of behaviorrelated disease, the occurrence of perimenopausal symptoms is closely associated with poor HPL. Due to the sedentary lifestyle perimenopausal symptoms, nursing shortage, low income, and social isolation, peri-menopausal women would often feel lonely and depressive, which might lead to lower probability of health-promoting behavior (Panay ret al., 2020).

\section{Research using PRECEDE-}

PROCEED model (PPM) approach for development of lifestyle interventions shows promising preliminary first results regarding outcome, as well as reach of the implemented programs. PPM is a framework that helps identifying specific intervention targets, allows the integration of individual and environmental factors into one concise program, and includes consideration of organizational, administrative and policy aspects that might hinder or support the practical implementation of a program (Bammann, et al., 2020).

The role of the nurse specialist in managing and supporting peri-menopausal women has been defined to take account of the need to facilitate a better understanding and the potential health implications of a well-managed peri-menopause among all nurses coming in contact with women, lead and develop specialist peri-menopause services, support services linked with all areas of care (Royal College of Nursing,2019).

According to research studies, lifestyle enhances people's health, maintains life length and is effective way of perimenopausal symptoms management. Previous studies have reported the positive correlation between health behavior and PPM in older people. However, there are no sufficient studies conducted on effect of PPM on lifestyle of peri-menopausal women (Li,et al.,2018). Hence, the present study had been conducted to analyze the effect of an educational program on lifestyle of perimenopausal women utilizing PPM .

\section{Aim of the study:}

This study aimed to investigate the effect of an educational program on lifestyle of perimenopausal women by utilizing PRECEDE - PROCEED model

\section{Research hypothesis:}

Perimenopausal women who received an educational program by utilizing PRECEDE PROCEED model would seek more to engage in health-promoting behaviours than those who didn't.

\section{Subjects and Method}

\section{Research design:}

Quasi-experimental equivalent study was followed to fulfill the aim of the study.

\section{Setting:}

This study was conducted at Administrative Building of Benha University hospitals.

\section{Sample:}

Type of sample: A purposive sample

Sample Size: All administrative perimenopausal women (122) working at Benha University hospitals. After application of 


\section{$\underline{\text { Gehad Gamal, Moharam Abdelhaseeb, Soad Abdel-Salam, and Samah Abdel-Haliem }}$}

inclusion and exclusion criteria, the final sample size was 109 women.

\section{-Inclusion criteria:}

Age (43-55) years, Natural perimenopause, Being married.

\section{- Exclusion criteria:}

Having severe stressors such as the death of close relatives during the last three months, women who were under medication for antidepressants, hypnotics, phytoestrogens and HRT, and those with a mental illness, Abnormal mass in the breast and/or any abnormality in the thyroid, History of hysterectomy and oophorectomy.

\section{Tools of Data collection:}

Tool I- A structured interviewing Questionnaire (Appendix I) was designed by the researcher after reviewing related literature (Moshki et al., 2018; Azar et al., 2018) and under the guidance of supervisors. It was written in an Arabic language in the form of close and open- ended questions. The questionnaire included two parts : The first part included :

- Socio-demographic characteristics.

- Menstrual and obstetrics history.

- Present history of perimenopausal symptom.

The second part included: The PRECEDEPROCEED model constructs: the questions were designed according to educationalecological assessment phase to determine predisposing, enabling and reinforcing factors.

- Predisposing factors included (3) sections (knowledge, attitude and selfefficacy)

- Section (I): Assessment of women's knowledge towards perimenopause and health-promoting lifestyle through (31) items written in Arabic language in the form of multiple choice questions: It consisted of (3) categories:

- Category (1) was concerned with knowledge regarding perimenopause and consisted of (7) items.
- Category (2) was concerned with knowledge regarding health-promoting lifestyle and consisted of (14) items .

- Category (3) was concerned with knowledge regarding healthy adaptive measures to overcome symptoms and consisted of (10) items.

\section{Knowledge's scoring system-:}

All knowledge variables were weighted according to items included in each question. Each item was given a score (2) when the answer was complete correct answer, a score (1) when the answer was incomplete correct answer and a score (0) when the answer was (I don't know). The total score of each category was calculated by summation of the scores of its items. The total score for the knowledge of each woman was calculated by the addition of the total score of all categories. The score of total knowledge (0 62) was classified as the following:

Good: $\quad(\geq 75 \%$ correct answers)

Average: $\quad(50-<75 \%$ correct answers $)$ Poor: (<50\% correct answers)

$\square$ Section (II): women's attitude towards perimenopause and lifestyle that was designed as Likert scale. This scale was adapted from Ghaderi et al., (2010) and contained 20 items.

\section{Scoring system:}

- Each item had 3-point Likert's scale ranging from (3) if the response was "agree", (2) if it was "sometimes", and (1) if it was "disagree ". the total score was calculated for each subject through summing up the points of the responses to each item and the mean attitude scale for each person was calculated as well.(10) items are positively worded (items 1-10) and (10) items are negatively worded (items 11-20). The score ranged from (20$60)$. High score indicates the favorable 


\section{PRECEDE - PROCEED Model}

attitude of women towards perimenopause and lifestyle .

- The total score of attitude was classified into:

Positive attitude: $\quad \geq 50 \%$

Negative attitude: $\quad<50 \%$

Section III: perimenopausal health selfefficacy scale: This scale is adapted from Reece and Harkless (2002) and is a 19-item Likertstyle scale generated to measure self-efficacy in coping with health issues germane to mid-life women. It contains four domains namely cognition and decision making behaviors (six items), mobilizing resources and coping behaviors (five items), control over health (six items), and enhancement of health behaviors (two items).

\section{Scoring system:}

- Each item was structured to measure the strength of a woman's belief that she could carry out a particular activity. Degrees of assurance for each item ranging from (1 3 ). (1) if the response is "I can't", (2) if the response is "I can do some extent " (3) if the response is "I can". A score for selfefficacy strength is obtained by calculating a mean of the women's responses to all items; four subscale scores are obtained similarly by calculating a mean of the responses to each subscale items. Range of possible mean self-efficacy scores rated from (19-57). Higher scores imply higher perimenopause health self-efficacy.

- The total score of self-efficacy was classified into:

- High self-efficacy: $\quad \geq 75 \%$

- Moderate self-efficacy: $50 \%<75 \%$

Low self-efficacy: $\quad<50 \%$

Reinforcing factors: designed by the researcher, included (6) questions to (measure support and encouragement of husband, family, friends, women of the same age and healthcare staff
3- Enabling factors designed by the researcher, included (6) questions to (measure access to information sources, attending workshops or seminars, the skills or experiences to understand information about different treatment methods and preventing complications,......etc. ( $·$.

- Scoring system of reinforcing and enabling factors:

- The answer choices to these questions were yes, no, and to some extent. A "no" answer was allocated a score of (1), "to some extent" was allocated a score of (2), and "yes" was allocated a score of (3).the total score of reinforcing and enabling factors ranged from (6-18). The total score is further classified into two levels: poor for the range (6-11) and strong for the range (12-18.(

\section{Tool II: health promoting lifestyle profile} (HPLP)

- A Likert-type scale was developed by Walker et al., 1987, was translated into Arabic language and was adapted by the researcher to assess the frequency of selfreported health-promoting behaviors. It comprised of (45) items divided into six dimensions which focus on different areas of lifestyle behaviors namely health responsibility (nine items), physical activity (four items), nutrition (eight items), spiritual growth (eight items), interpersonal relations (eight items), and stress management (eight items .(

\section{Scoring system:}

- A score for overall health-promoting lifestyle was obtained by calculating a mean of the women's responses to all items; six subscale scores were obtained similarly by calculating a mean of the responses to subscale items. It used a four-point response scale that indicated respondents' frequency of engaging in each behavior. Items were scored as (1)= "never", 


\section{Gehad Gamal, Moharam Abdelhaseeb, Soad Abdel-Salam, and Samah Abdel-Haliem}

(2) = "sometime", (3) = "often", $(4)=$ "routinely". The total score of the HPLP II ranged from 45 to 180 and was measured by the mean score of the responses to all 45 HPLP items. The total HPLP II score was further classified into four levels: poor for the range (45-90), moderate for the range $(91-136)$, good for the range (137-180). Higher scores showed more healthy promoting behaviors.

\section{Validity and reliability of tools:}

The tool was developed and translated into Arabic after reviewing the current and past national and international relevant literature related to PPM, perimenopause and lifestyle, by using local and international books, journals, periodicals and computer searches then tool was reviewed by 3 jury experts in the field of obstetrics and woman's health nursing . Cronbach's alpha coefficient test was calculated to assess the reliability that indicated that tool consisted of relatively homogenous items as indicated by the moderate to high reliability.

\section{Ethical Considerations:}

- An official permission from the selected study setting was obtained for the fulfillment of the study. The aim of the study was explained to each woman before applying the tools at the beginning of interview and time throughout the study to gain her confidence and trust.The researcher took oral consent from each woman to participate in the study and withdraw when she needs.

\section{Pilot Study:}

A pilot study has been conducted on $10 \%$ of the total sample (11) women before starting data collection to test the clarity and applicability of study tools, asses the feasibility of the fieldwork and determine the time needed to fill in the questionnaire. There were no modifications done. Thus, women involved in the pilot study were included in the study.

\section{Field work:}

The study was conducted through PRECEDE - PROCEED model phases. At first, the PRECEDE four- phase assessments were conducted and then an appropriate intervention based on the assessments was developed, implemented and evaluated. Study was carried out from the beginning of June, 2019 and completed at the end of October, 2020 covering 17 months. The researcher visited the previously mentioned setting three days/week (Sunday, Tuesday and Thursday) from 9.00 Am to 2.00 Pm.

\section{Phase 1: Social assessment:}

In this phase, factors affecting the health promotion and quality of life during perimenopause were evaluated by using different data collection tools after reviewing related literature.

At the beginning of the interview, the researcher introduced herself, greeted each woman and explained the purpose of the study. She took an oral consent from women to participate in the study then, distributed, HPLP II (Pretest) to collect data about the women's behaviors. The average time required for completing the questionnaire was around (15-20 minutes). The researcher observed that bad health behaviors, social withdrawal and stress, were the main problems that hinder promoting of health.

\section{Phase 2: Epidemiological, behavioral and environmental assessment:}

Epidemiological assessment: In this phase, researcher collected existing data regarding significance and prevalence of lifestyle and factors associated with it during perimenopause in Egypt and other countries, using various online databases.

\section{Behavioral and environmental assessment:}

The researcher distributed a structured interviewing questionnaire (Appendix I - first 
part) (pretest) to collect date about sociodemographic characteristics, menstrual and obstetrics data, and present perimenopausal symptoms .The researcher weighed each woman and measured her height to estimate $(\mathbf{B M I})=$ weight $(\mathrm{kg}) /$ height $(\mathrm{m})^{2}$.

After that, questionnaire based on PRECEDE - PROCEED model constructs (predisposing, reinforcing and enabling factors) was completed (pretest). The average time required for completion of the questionnaire was around (30-40 minutes).

- Each woman was interviewed individually. The number of interviewed women per week was 9-12 women (3-4 women/day). The average time taken for completing each sheet was around (45-60) minutes depending on the response of the women. Each woman was reassured that obtained information would be confidential and used only for the purpose of the study. Scheduled times and frequency of program sessions to selected women to assure adherence to selected interventions.

The most important factors were found, the defect in the dominant factors affecting lifestyle during this period in addition to limited access to informational resources such as educational materials, classes and databases, poor time management, and lack of support. Some demographic variables such as education, work conditions and monthly income were also considered important factors affecting lifestyle in target population.

\section{Phase 3: Educational and ecological assessment:}

In this phase, predisposing, enabling, and reinforcing factors were reviewed. In a primary review of the literature by the researcher, knowledge, attitude, and selfefficacy were chosen as predisposing factors. Enabling factors included access to databases and attending educational courses. Reinforcing factors included family support by the husband and friends and verbal encouragement. A previous standard researcher-designed questionnaire was prepared as such.

\section{Phase 4: Administrative and policy assessments:}

In this phase, the necessary official permissions for data collection were obtained by submission an official letter issued from the dean of Benha nursing faculty and directed to the director of Benha university hospitals to obtain the official agreement to conduct the study. The title and objectives of study were illustrated.

Researchers selected a location and prepared a timetable for the responsibilities and did the necessary coordination of educational and environmental interventions. These items were collected via interviewing the participants. Based on results obtained from pre-program assessment, and the existing relevant scientific resources (Ebrahimi and Rahimi , 2019), the researcher designed a booklet in an Arabic language supported by figures based on women's knowledge deficit about perimenopause, health-promoting lifestyle and healthy adaptive measures to overcome symptoms. The educational program was developed using PRECEDE - PROCEED model as a guideline, sessions number and its contents, different methods of teaching, and instructional media were determined accordingly to study group. Telephone number was obtained from women to facilitate contact in women who couldn't attend their planned program schedule.

Program's objectives were constructed and included the following:

General objective: 


\section{Gehad Gamal, Moharam Abdelhaseeb, Soad Abdel-Salam, and Samah Abdel-Haliem}

By the end of the educational program, the study group would have positive lifestyle modifications in the six aspects of the health -promoting lifestyle.

\section{Specific objectives:-}

- To acquire essential knowledge regarding perimenopause, health promoting lifestyle and healthy adaptive measures.

- To adopt a positive outlook towards perimenopause and lifestyle modification.

- To have the strength of belief in performing decision making behaviors, mobilizing resources, coping behaviors, control over health and enhancement of health behaviors.

- To be aware of reinforcing and enabling factors for lifestyle modification during perimenopause.

\section{Phase 5: Implementation:}

A group-based educational program according to PRECEDE - PROCEED model was conducted to study group through five sessions over a period of (22) weeks. Participants (study group) were classified to (20) subgroups. Total time for all sessions took about four hours and half, each session took about (45-60) minutes. The sessions were repeated to each subgroup each subgroup (2-3 women / session). At the beginning of the first session women were oriented with the program contents. Each subgroup was informed about the time of the next sessions at the end of session. The subsequent session started by a feedback about the previous session and the objectives of the new session, using simple Arabic language to suit women's level of understanding. Various educational methods (group discussion, role-playing, demonstration and re-demonstration) and materials (power point presentation, video film, a designed booklet) were used .At the end of each session; women's questions were discussed to correct any misunderstanding. The researcher asked the participants to transfer the training program to their families and peers to foster reinforcing and enabling factors.

The first session: at the beginning, the researcher gave the women the educational booklet and introduced an orientation to the program, introduction about perimenopause, causes, risk factors, and perimenopausal symptoms.

* The second session focused on general knowledge methods of perimenopause management, and standards of health-promoting lifestyle (health responsibility "periodic checks and investigations", and importance of exercise, rate and types of exercises).

* The third session focused on nutrition, interpersonal relations, and spiritual growth. Women were taught about balanced diet, modifying unhealthy nutritional behaviors, strict intake of processed and sugar rich foods and carbohydrates, increasing intake of fresh vegetables and fruits, increasing dairy intake. As well as, maintaining weight control and reducing obesity. Social support and maintaining communications with others, overcoming the embarrassment and strengthening talking with the husband about perimenopause.

The fourth session focused on stress management, measures to minimize and cope with stress; relaxing activities such as slow and deep breathing exercises, or listening to 


\section{PRECEDE - PROCEED Model}

music and adaptive healthy measures for symptoms.

* The fifth session focused on PRECEDE - PROCEED model constructs, its phases and predisposing, reinforcing and enabling factors for healthy lifestyle during perimenopause.

\section{Phase 6: Evaluation of the process:}

The process (methods, materials and activities used), by which the program was being operated, was assessed through considering the progression of the participants response based on predetermined educational objectives during implementation of the program. The researcher ensured adherence of the study group to the program via telephone and whatsapp group.

\section{Phase 7: Evaluation of impact and outcome:}

During this phase, the women's predisposing factors, reinforcing factors, enabling factors and health-promoting lifestyle as indicators of this program were evaluated (posttest was performed three months after the intervention) by using the same format of tools which were used before the program implementation for both groups. Evaluation started first with control group then with study group to avoid bias. Follow up was scheduled six months after the program application. The researcher followed women via telephone and whatsapp group due to COVID- 19 circumstances. The participants in the control group were given the booklet.

\section{Statistical analysis:}

Data entry and statistical analysis were done using SPSS 20.0 statistical software package.

\section{Results:}

Table (1) shows that the mean age of control and study groups were $48.51 \pm 3.34$ and $47.69 \pm 3.64$ years respectively. Regarding residence, $63 \%$ of the control group and $72.7 \%$ of the study group live in rural areas. More than half of both groups had secondary education. The mean age at marriage of control and study groups $20.20 \pm$ 2.07 and $21.01 \pm 3.5 \quad$ respectively, moreover the mean duration of marriage of control and study groups were $28.44 \pm 4.45$ and $\quad 26.83 \pm 5.43$ respectively. Regarding nature of work, $68.2 \%$ of the control group and $78.2 \%$ of the study group had psychological nature of work. Also, the mean number of work years of control and study groups were $23.07 \pm 6.021$ and $23.60 \pm$ 6.96 respectively. Most of both groups had no enough monthly income, whereas only $22.2 \%$ of the control group and $34.5 \%$ of the study group had enough monthly income. There was no statistically significant difference between both groups regarding personal characteristics $(\mathrm{p}>0.05)$. The two groups under study were homogeneous

Table (2) clarifies that mean age of menarche of both control and study groups were $12.166 \pm 1.041$ and $11.83 \pm .897$ respectively. Regarding status of menstruation $85.2 \%$ of the control group were menstruated while $76.4 \%$ of the study group were menstruated. Regarding interval and duration of menstruation, the mean interval and duration of control group were $39.75 \pm 18.03$ and $4.81 \pm 2.21$ respectively, but the mean interval and duration of study group were $37.47 \pm 19.11$ and $4.69 \pm 1.73$ respectively. 
Moreover $45.7 \%$ of the control group and $40.5 \%$ of the study group had moderate amount of menstruation. Most of both groups had liquid blood. More than half of control and study groups suffered from pain accompanied with menstruation $(58.7 \%$ and $71.4 \%$ respectively). Also there was no statistically significant difference among the studied groups regarding menstrual history ( $p>0.05)$.

Table (3) clarifies that there was no statistically significant difference between control and study groups regarding predisposing, reinforcing, enabling factors and health promoting lifestyle before PPM application $(p>0.05)$. However, there was a highly statistically significant difference was observed in predisposing, reinforcing, and enabling factors and health promoting lifestyle of the study group compared with the control group after three and six months of PPM application ( $\mathrm{p}<0.001)$.

Table (4) shows that there was no statistically significant difference in the mean scores of the total health promoting lifestyle behaviors and its dimensions between the two groups before the program application $(\mathrm{p}>$ $0.05)$. However, after three and six months of program application, the mean difference scores for the total health promoting lifestyle behaviors and its dimensions in the study group was higher than the scores in the control group $(\mathrm{p}<0.001)$. 
Table (1): Distribution of control and study groups according to socio-demographic characteristics(n=109):

\begin{tabular}{|c|c|c|c|c|c|c|}
\hline \multirow[b]{2}{*}{ Personal characteristics } & \multicolumn{2}{|c|}{$\begin{array}{c}\text { Control group } \\
(n=54)\end{array}$} & \multicolumn{2}{|c|}{$\begin{array}{c}\text { Study group } \\
(n=55)\end{array}$} & \multirow[t]{2}{*}{$\mathbf{X}^{2}$} & \multirow[t]{2}{*}{$P$ - value } \\
\hline & No & $\%$ & No & $\%$ & & \\
\hline \multicolumn{7}{|l|}{ Age (years) } \\
\hline - $43-<47$ & 13 & 24.1 & 18 & 32.7 & \multirow{3}{*}{1.803} & \multirow{3}{*}{0.406} \\
\hline - $\quad 47-<51$ & 23 & 42.6 & 17 & 30.9 & & \\
\hline - $51-\leq 55$ & 18 & 33.3 & 20 & 36.4 & & \\
\hline Mean \pm SD & \multicolumn{2}{|c|}{$48.51 \pm 3.34$} & \multicolumn{2}{|c|}{$47.69 \pm 3.64$} & $\mathrm{t}=1.235$ & 0.220 \\
\hline \multicolumn{7}{|l|}{ Residence } \\
\hline - Rural & 34 & 63 & 40 & 72.7 & \multirow{2}{*}{1.192} & \multirow{2}{*}{0.275} \\
\hline - Urban & 20 & 37 & 15 & 27.3 & & \\
\hline \multicolumn{7}{|l|}{ Educational level } \\
\hline - $\quad$ Primary education & 5 & 9.3 & 4 & 7.3 & \multirow{3}{*}{$0.552^{€}$} & \multirow{3}{*}{0.759} \\
\hline - Secondary education & 30 & 55.6 & 28 & 50.9 & & \\
\hline - University education & 19 & 35.2 & 23 & 41.8 & & \\
\hline \multicolumn{7}{|l|}{ Duration of marriage ( years) } \\
\hline - $10-<20$ & 2 & 3.7 & 6 & 10.9 & $2080^{\epsilon}$ & 0271 \\
\hline - $20-\geq 30$ & 52 & 96.3 & 49 & 89.1 & & \\
\hline Mean \pm SD & \multicolumn{2}{|c|}{$28.44 \pm 4.45$} & \multicolumn{2}{|c|}{$26.83 \pm 5.43$} & $t=1.673$ & 0.097 \\
\hline \multicolumn{7}{|l|}{ Number of work years } \\
\hline - $1-<10$ & 3 & 5.6 & 2 & 3.6 & \multirow{3}{*}{$1.305^{€}$} & \multirow{3}{*}{0.521} \\
\hline - $10-<20$ & 10 & 18.5 & 15 & 27.3 & & \\
\hline - $\quad \geq 20$ & 41 & 75.9 & 38 & 69.1 & & \\
\hline Mean \pm SD & \multicolumn{2}{|c|}{$23.07 \pm 6.021$} & \multicolumn{2}{|c|}{$23.60 \pm 6.96$} & $\mathrm{t}=0.431$ & 0.667 \\
\hline \multicolumn{7}{|l|}{ Monthly income } \\
\hline - Enough & 12 & 22.2 & 19 & 34.5 & \multirow{2}{*}{2.033} & \multirow{2}{*}{0.154} \\
\hline - Not enough & 42 & 77.8 & 36 & 65.5 & & \\
\hline
\end{tabular}

No statistical significant difference $(\mathrm{p}>0.05) \quad \mathrm{t}=$ independent $\mathrm{t}$ test $\quad €$ Fisher Exact Test 
Gehad Gamal, Moharam Abdelhaseeb, Soad Abdel-Salam, and Samah Abdel-Haliem

Table (2): Distribution of control and study groups according to menstrual history $(\mathbf{n}=109)$ :

\begin{tabular}{|c|c|c|c|c|c|c|}
\hline \multirow[t]{2}{*}{ Menstrual history } & \multicolumn{2}{|c|}{$\begin{array}{c}\text { Control } \\
\text { group } \\
(n=54) \\
\end{array}$} & \multicolumn{2}{|c|}{$\begin{array}{c}\text { Study group } \\
(n=55)\end{array}$} & \multirow[t]{2}{*}{$\mathbf{X}^{2}$} & \multirow[t]{2}{*}{ P - value } \\
\hline & No & $\%$ & No & $\%$ & & \\
\hline \multicolumn{7}{|l|}{ Age of menarche } \\
\hline Mean \pm SD & \multicolumn{2}{|c|}{$12.166 \pm 1.041$} & \multicolumn{2}{|c|}{$11.83 \pm .897$} & $\mathrm{t}=1.774$ & 0.079 \\
\hline \multicolumn{7}{|l|}{ Menstruated } \\
\hline - Yes & 46 & 85.2 & 42 & 76.4 & \multirow{2}{*}{1.363} & \multirow{2}{*}{0.355} \\
\hline - No & 8 & 14.8 & 13 & 23.6 & & \\
\hline Interval ( days) & \multicolumn{2}{|c|}{$n=46$} & \multicolumn{2}{|c|}{$n=42$} & & \\
\hline - $\leq 20$ & 5 & 10.9 & 7 & 16.6 & & \multirow{3}{*}{0.569} \\
\hline - $21-35$ & 16 & 34.8 & 13 & 31 & 2.017 & \\
\hline - $\geq 36$ & 25 & 54.3 & 22 & 52.4 & & \\
\hline Mean \pm SD & \multicolumn{2}{|c|}{$39.75 \pm 18.03$} & \multicolumn{2}{|c|}{$37.47 \pm 19.11$} & $\mathrm{t}=0.642$ & 0.522 \\
\hline \multicolumn{7}{|l|}{ Duration ( days) } \\
\hline - $<3$ & 10 & 21.7 & 8 & 19 & \multirow{3}{*}{2.342} & \multirow{3}{*}{0.504} \\
\hline - $3-<7$ & 27 & 58.7 & 22 & 52.4 & & \\
\hline - $\geq 7$ & 9 & 19.6 & 12 & 28.6 & & \\
\hline Mean \pm SD & \multicolumn{2}{|c|}{$4.81 \pm 2.21$} & \multicolumn{2}{|c|}{$4.69 \pm 1.73$} & $\mathrm{t}=0.305$ & 0.761 \\
\hline \multicolumn{7}{|l|}{ Daily amount of menstruation } \\
\hline - $\quad$ Mild amount (2 pads or less) & 8 & 17.4 & 10 & 23.8 & \multirow{3}{*}{1.950} & \multirow{3}{*}{0.583} \\
\hline - Moderate amount (3-4 pads) & 21 & 45.7 & 17 & 40.5 & & \\
\hline - Severe amount (5pads or more) & 17 & 36.9 & 15 & 35.7 & & \\
\hline \multicolumn{7}{|l|}{ Nature of menstruation } \\
\hline - Liquid blood & 39 & 84.8 & 34 & 80.9 & \multirow{2}{*}{1.591} & \multirow{2}{*}{0.451} \\
\hline - Clotting blood & 7 & 15.2 & 8 & 19.1 & & \\
\hline \multicolumn{7}{|l|}{ Pain accompanied with menstruation } \\
\hline - Yes & 27 & 58.7 & 20 & 47.6 & \multirow{2}{*}{1.580} & \multirow{2}{*}{0.209} \\
\hline - No & 19 & 41.3 & 22 & 52.4 & & \\
\hline
\end{tabular}

$\mathrm{t}=$ independent $\mathrm{t}$ test

No statistical significant

difference $(p>0.05)$ 


\section{Application of an Educational Program on Lifestyle of Perimenopausal Women Utilizing PRECEDE - PROCEED Model}

Table (3): Comparison of the mean scores of educational and ecological assessment phase structures of PPM and the total life style score of control and study groups through times of assessment $(n=109)$ :

\begin{tabular}{|c|c|c|c|c|c|c|c|c|c|c|c|c|c|}
\hline \multirow{3}{*}{ Items } & \multirow{3}{*}{$\begin{array}{c}\text { Maxim } \\
\text { um } \\
\text { score }\end{array}$} & \multicolumn{2}{|c|}{$\begin{array}{c}\text { Before program } \\
\text { application }\end{array}$} & \multirow{3}{*}{$\begin{array}{c}\text { t } \\
\text { test }\end{array}$} & \multirow{3}{*}{$\begin{array}{l}P \text { - } \\
\text { value }\end{array}$} & \multicolumn{2}{|c|}{$\begin{array}{c}3 \text { months after program } \\
\text { application }\end{array}$} & \multirow{3}{*}{ t test } & \multirow{3}{*}{$\begin{array}{l}P \text { - } \\
\text { value }\end{array}$} & \multicolumn{2}{|c|}{$\begin{array}{c}6 \text { months after program } \\
\text { application }\end{array}$} & \multirow{3}{*}{ t test } & \multirow{3}{*}{$\begin{array}{l}P \text { - } \\
\text { value }\end{array}$} \\
\hline & & $\begin{array}{c}\text { Control } \\
\text { group } \\
\mathrm{n}=\mathbf{5 4}\end{array}$ & $\begin{array}{l}\text { Study } \\
\text { group } \\
\mathbf{n}=\mathbf{5 5}\end{array}$ & & & $\begin{array}{c}\text { Control } \\
\text { group } \\
\mathrm{n}=54 \\
\end{array}$ & $\begin{array}{l}\text { Study } \\
\text { group } \\
\mathbf{n}=\mathbf{5 5} \\
\end{array}$ & & & $\begin{array}{c}\text { Control } \\
\text { group } \\
\mathrm{n}=54 \\
\end{array}$ & $\begin{array}{l}\text { Study } \\
\text { group } \\
\mathbf{n}=\mathbf{5 5} \\
\end{array}$ & & \\
\hline & & $\begin{array}{l}\text { Mean } \pm \\
\text { SD }\end{array}$ & $\begin{array}{l}\text { Mean } \pm \\
\quad \text { SD }\end{array}$ & & & Mean \pm SD & Mean \pm SD & & & Mean \pm SD & Mean \pm SD & & \\
\hline \multicolumn{14}{|c|}{\begin{tabular}{|l|} 
Predisposing factors \\
\end{tabular}} \\
\hline attitude & 60 & $\begin{array}{l}32.66 \pm \\
4.83\end{array}$ & $\begin{array}{l}33.34 \\
\pm 2.86\end{array}$ & $\begin{array}{l}0.89 \\
4\end{array}$ & 0.374 & $\begin{array}{l}33.75 \pm \\
4.17\end{array}$ & $48.14 \pm 5.83$ & $\begin{array}{l}14.76 \\
8\end{array}$ & $\begin{array}{l}0.000 * \\
*\end{array}$ & $\begin{array}{l}33.33 \pm \\
3.86\end{array}$ & $51.43 \pm 6.77$ & $\begin{array}{c}17.10 \\
5\end{array}$ & $\begin{array}{c}0.000 * \\
*\end{array}$ \\
\hline \begin{tabular}{|l|} 
Self-efficacy \\
\end{tabular} & 57 & $\begin{array}{l}30.85 \pm \\
4.64\end{array}$ & $\begin{array}{l}31.87 \pm \\
3.66\end{array}$ & $\begin{array}{l}1.90 \\
7\end{array}$ & 0.060 & $\begin{array}{l}32.12 \pm \\
3.80\end{array}$ & $46.21 \pm 5.24$ & $\begin{array}{l}16.02 \\
5\end{array}$ & $\begin{array}{l}0.000^{*} \\
*\end{array}$ & $31.50 \pm 3.26$ & $48.56 \pm 5.46$ & $\begin{array}{l}19.73 \\
8\end{array}$ & $\begin{array}{c}0.000 * \\
*\end{array}$ \\
\hline $\begin{array}{l}\text { Reinforcing } \\
\text { factors }\end{array}$ & 18 & $\begin{array}{c}11.61 \pm \\
\mathbf{1 . 8 1}\end{array}$ & $11.40 \pm \mathbf{1 . 8 8}$ & $\begin{array}{l}0.59 \\
6\end{array}$ & 0.553 & $\begin{array}{c}11.44 \pm \\
1.78\end{array}$ & $13.81 \pm 1.49$ & 7.533 & $\begin{array}{l}0.000^{*} \\
*\end{array}$ & $\begin{array}{c}11.46 \pm \\
1.81\end{array}$ & $14.43 \pm 1.53$ & 9.244 & $\begin{array}{c}0.000 * \\
*\end{array}$ \\
\hline
\end{tabular}

No statistical significant difference $(\mathrm{p}>0.05)$

*Statistically significant $(\mathrm{P} \leq 0.05) \quad * *$ A high statistical significant difference $(\mathrm{P} \leq 0.001)$ 


\section{Gehad Gamal, Moharam Abdelhaseeb, Soad Abdel-Salam, and Samah Abdel-Haliem}

Table (4): Comparison between the mean health promoting lifestyle scores of control and study groups through times of assessment (n=109):

\begin{tabular}{|c|c|c|c|c|c|c|c|c|c|c|c|c|c|}
\hline \multirow[b]{3}{*}{ Items } & \multirow{3}{*}{$\begin{array}{c}\text { Maxim } \\
\text { um } \\
\text { score }\end{array}$} & \multicolumn{2}{|c|}{$\begin{array}{c}\text { Before program } \\
\text { application }\end{array}$} & \multirow{3}{*}{$\begin{array}{c}\text { t } \\
\text { test }\end{array}$} & \multirow{3}{*}{$\begin{array}{l}P \text { - } \\
\text { value }\end{array}$} & \multicolumn{2}{|c|}{$\begin{array}{c}3 \text { months after } \\
\text { program application }\end{array}$} & \multirow{3}{*}{ t test } & \multirow{3}{*}{$\begin{array}{l}P \text { - } \\
\text { value }\end{array}$} & \multicolumn{2}{|c|}{$\begin{array}{c}6 \text { months after program } \\
\text { application }\end{array}$} & \multirow{3}{*}{ t test } & \multirow{3}{*}{$\begin{array}{l}P \text { - } \\
\text { value }\end{array}$} \\
\hline & & $\begin{array}{c}\text { Control } \\
\text { group } \\
n=54\end{array}$ & $\begin{array}{l}\text { Study } \\
\text { group } \\
\mathbf{n}=\mathbf{5 5}\end{array}$ & & & $\begin{array}{c}\text { Control } \\
\text { group } \\
n=54\end{array}$ & $\begin{array}{l}\text { Study } \\
\text { group } \\
\mathbf{n}=\mathbf{5 5}\end{array}$ & & & $\begin{array}{c}\text { Control } \\
\text { group } \\
\mathbf{n}=\mathbf{5 4}\end{array}$ & $\begin{array}{l}\text { Study } \\
\text { group } \\
\mathbf{n}=\mathbf{5 5}\end{array}$ & & \\
\hline & & $\begin{array}{c}\text { Mean } \pm \\
\text { SD }\end{array}$ & $\begin{array}{c}\text { Mean } \pm \\
\text { SD }\end{array}$ & & & $\begin{array}{c}\text { Mean } \pm \\
\text { SD }\end{array}$ & Mean \pm SD & & & $\begin{array}{c}\text { Mean } \pm \\
\text { SD }\end{array}$ & Mean \pm SD & & \\
\hline $\begin{array}{l}\text { Health } \\
\text { responsibility }\end{array}$ & 36 & $\begin{array}{c}16.87 \pm \\
2.24\end{array}$ & $\begin{array}{c}17.34 \pm \\
2.33\end{array}$ & $\begin{array}{c}1.08 \\
3\end{array}$ & 0.281 & $\begin{array}{c}17.27 \pm \\
2.33\end{array}$ & $\begin{array}{c}23.94 \pm \\
2.59\end{array}$ & $\begin{array}{c}14.46 \\
3\end{array}$ & $\begin{array}{c}0.000^{*} \\
*\end{array}$ & $\begin{array}{c}17.62 \pm \\
2.83\end{array}$ & $25.52 \pm 2.87$ & 14.455 & $\begin{array}{c}0.000 * \\
*\end{array}$ \\
\hline Physical activity & 16 & $6.90 \pm 1.47$ & $\begin{array}{c}6.87 \pm \\
1.55\end{array}$ & $\begin{array}{c}0.12 \\
0\end{array}$ & 0.905 & $\begin{array}{c}7.00 \pm \\
1.55\end{array}$ & $\begin{array}{c}10.18 \pm \\
1.32\end{array}$ & $\begin{array}{c}11.52 \\
6\end{array}$ & $\begin{array}{c}0.000^{*} \\
*\end{array}$ & $\begin{array}{c}6.90 \pm \\
1.50\end{array}$ & $10.87 \pm 1.47$ & 13.860 & $\begin{array}{c}0.000^{*} \\
*\end{array}$ \\
\hline Nutrition & 32 & $\begin{array}{c}17.85 \pm \\
3.28\end{array}$ & $\begin{array}{c}17.63 \pm \\
3.03\end{array}$ & $\begin{array}{c}0.35 \\
6\end{array}$ & 0.732 & $\begin{array}{c}18.03 \pm \\
3.82\end{array}$ & $\begin{array}{c}22.23 \pm \\
3.94\end{array}$ & 5.637 & $\begin{array}{c}0.000^{*} \\
*\end{array}$ & $\begin{array}{c}17.42 \pm \\
3.46\end{array}$ & $\begin{array}{c}23.69 \pm \\
3.99\end{array}$ & 8.737 & $\begin{array}{c}0.000^{*} \\
*\end{array}$ \\
\hline Spiritual growth & 32 & $\begin{array}{c}16.88 \pm \\
2.08\end{array}$ & $\begin{array}{c}16.74 \pm \\
1.94\end{array}$ & $\begin{array}{c}0.37 \\
1\end{array}$ & 0.711 & $\begin{array}{c}17.11 \pm \\
1.98\end{array}$ & $\begin{array}{c}22.69 \pm \\
1.74\end{array}$ & $\begin{array}{c}15.59 \\
8\end{array}$ & $\begin{array}{c}0.000^{*} \\
*\end{array}$ & $\begin{array}{c}17.48 \pm \\
2.09\end{array}$ & $23.85 \pm 2.40$ & 14.855 & $\begin{array}{c}0.000^{*} \\
*\end{array}$ \\
\hline $\begin{array}{l}\text { Interpersonal } \\
\text { relationship }\end{array}$ & 32 & $\begin{array}{c}18.31 \pm \\
2.68\end{array}$ & $\begin{array}{c}17.96 \pm \\
2.63\end{array}$ & $\begin{array}{c}0.69 \\
0\end{array}$ & 0.492 & $\begin{array}{c}18.85 \pm \\
2.97\end{array}$ & $\begin{array}{c}23.70 \pm \\
2.43\end{array}$ & 9.330 & $\begin{array}{c}0.000^{*} \\
*\end{array}$ & $\begin{array}{c}18.98 \pm \\
3.11\end{array}$ & $24.43 \pm 2.95$ & 9.378 & $\begin{array}{c}0.000^{*} \\
*\end{array}$ \\
\hline $\begin{array}{l}\text { Stress } \\
\text { management }\end{array}$ & 32 & $\begin{array}{c}14.74 \pm \\
2.03\end{array}$ & $\begin{array}{c}14.76 \pm \\
2.15\end{array}$ & $\begin{array}{c}0.49 \\
9\end{array}$ & 0.619 & $\begin{array}{c}15.31 \pm \\
1.95\end{array}$ & $\begin{array}{c}22.54 \pm \\
2.52\end{array}$ & $\begin{array}{c}16.68 \\
9\end{array}$ & $\begin{array}{c}0.000^{*} \\
*\end{array}$ & $\begin{array}{c}15.09 \pm \\
2.25\end{array}$ & $23.65 \pm 2.82$ & 17.461 & $\begin{array}{c}0.000^{*} \\
*\end{array}$ \\
\hline Total score & 180 & $\begin{array}{c}91.57 \pm \\
8.78\end{array}$ & $\begin{array}{c}91.32 \pm \\
8.14\end{array}$ & $\begin{array}{c}0.15 \\
2\end{array}$ & 0.879 & $\begin{array}{c}93.37 \pm \\
8.45\end{array}$ & $\begin{array}{c}125.45 \pm \\
6.45\end{array}$ & $\begin{array}{c}22.29 \\
1\end{array}$ & $\begin{array}{c}0.000^{*} \\
*\end{array}$ & $\begin{array}{c}93.46 \pm \\
8.91\end{array}$ & $\begin{array}{c}132.03 \pm \\
10.81\end{array}$ & 20.303 & $\begin{array}{c}0.000^{*} \\
*\end{array}$ \\
\hline
\end{tabular}

No statistical significant difference $(\mathrm{p}>0.05)$

*Statistically significant $(\mathrm{P} \leq 0.05) \quad * *$ A high statistical significant difference $(\mathrm{P} \leq 0.001)$. 


\section{Discussion:}

Regarding socio-demographic characteristics of the studied groups, the results of the present study cleared that there was no statistically significant difference among the studied groups regarding their personal characteristics (age, level of education, residence, age at marriage, duration of marriage, nature of work, and monthly income). This may be due to homogeneity of the study population.

This result is in accordance with Afshari et al., (2020) who studied "Menopause uncertainty: the impact of two educational interventions among women during menopausal transition and beyond" and reported that the two groups had no significant differences in demographic characteristics such as age, and education. This result also agrees with Narjes et al.(2020) who studied "the effects of menopausal health training for spouses on women's quality of life during menopause transitional period" and reported that the two groups had no significant differences in demographic characteristics such as age, residence and education level

The world health organization defines peri-menopause as a period (2-8 years) before menopause and one year after the last menstrual period resulting from loss of ovarian follicular activity (Who, 2018). The results of the current study revealed that more than one third of the studied groups were 47 $<51$ years old with a mean age of control and study groups were $48.51 \pm 3.34$ and $47.69 \pm$ 3.64 years respectively. This result comes in the same line with Willi et al., (2020) who studied "Prior depression affects the experience of the perimenopause - findings from the Swiss Perimenopause Study" and concluded that the mean age of perimenopausal women was $48.6 \pm 3.9$.

This result is also supported by Delamater and Santoro, (2018) who studied "Management of the Perimenopause" and found that age of the studied women ranges from 45-50 years old. Also the result is nearly similar to Faraji et al., (2018) who studied "Could a Midwife Leading Health Behavior Counseling Improve Self-Care of Women During Perimenopause?" and found that the age of 42 participants in the study was 39-51 years with a mean age of $45.50 \pm 3.04$.

Regarding residence, more than half of control and study groups lived in rural areas and had secondary education. The most frequent influencing factors of perimenopausal symptoms were educational level, residence, monthly income. This result is consistent with Faraji et al., (2018) who reported that more than half of the studied women had secondary education. Also this result is nearly similar to Gebretatyos et al., (2020) who studied "Effect of health education on knowledge and attitude among middle-age" and found that more than half of the studied women had moderate level of education.

In relation to duration of marriage, the results of the present study clarified that duration of marriage of more than three quarters of the studied groups was $20-\geq 30$ years. This result nearly agrees with Koçak and Beji, (2019) who studied "Effect of Health Promoting Lifestyle Education Program on reducing the menopausal symptoms of women in Turkey" and mentioned that duration of marriage of more than half of the women in the control and intervention group was (33-44 years).

As regards monthly income, the results of the present study demonstrated that 


\section{Gehad Gamal, Moharam Abdelhaseeb, Soad Abdel-Salam, and Samah Abdel-Haliem}

most of both groups had no enough monthly income. This result is nearly similar to Gebretatyos et al., (2020) who reported that more than half of the studied women had moderate level of monthly income. This result also agrees with Sis Çelik and Pasinlioğlu (2019) who found that two thirds of the studied groups had medium income level. So, poverty, low level of education, and early marriage age are other contributing factors that can lead to sedentary lifestyle.

In relation to menstrual history, the results of the present study clarifies that there was no statistically significant difference among the studied groups regarding menstrual history ( $p>0.05$ ). The two groups under study were homogeneous. This result is in accordance with Afshari et al., (2020) who found that there was no statistically significant difference among the studied groups regarding age of menarche and interval of menstruation.

The results of the present study indicates that mean age of menarche of both control and study groups were $12.166 \pm 1.041$ and $11.83 \pm .897$ respectively. Farland, et al., (2017) made a study on "Menstrual cycle characteristics and steroid hormone, prolactin, and growth factor levels in premenopausal women" and found that the majority of women were 12 or 13 years old at menarche.

Regarding status of menstruation the results of the present study clarifies more than two thirds of the control and study groups were menstruated This result nearly agrees with Ebrahimi and Rahimi, (2019) who found that nearly two thirds of the intervention and control groups were menstruated.

Regarding interval and duration of menstruation, the mean interval and duration of control group were $39.75 \pm 18.03$ and $4.81 \pm 2.21$ respectively, but the mean interval and duration of study group were $37.47 \pm$ 19.11 and $4.69 \pm 1.73$ respectively. Moreover $45.7 \%$ of the control group and $40.5 \%$ of the study group had moderate amount of menstruation. Most of both groups had liquid blood. More than half of control and study groups suffered from pain accompanied with menstruation $\quad(58.7 \%$ and $71.4 \%$ respectively).

Yisma, et al., (2017) studied "Prevalence and severity of menopause symptoms among perimenopausal and postmenopausal women aged 30-49 years in Gulele sub-city of Addis Ababa, Ethiopia" and mentioned that peri-menopausal status included women experiencing irregular menses within the last 12 months or an absence of menstrual bleeding for more than 3 months but less than 12 months. Based on the results of Bae, et al., (2018) who studied "Factors associated with menstrual cycle irregularity and menopause" and concluded that women ( $\geq 25 \mathrm{~kg} / \mathrm{m} 2 \mathrm{BMI})$ showed higher risk of irregular menstruation than normalweight women $\left(25-<30 \mathrm{~kg} / \mathrm{m}^{2}\right)$.

As regards present history of perimenopausal symptoms, the results of the present study illustrates that more than half of women in the control and study groups complained of multiple symptoms as hot flushes, night sweating, sleep disorders , irregular menstruation, weight gain, hair loss, vaginal dryness, low arousal, joint and muscles pain, low concentration, nervousness, mood Swings, and depression. This result agrees with Du, et al., (2020) who studied "Menopausal Symptoms and Perimenopausal Healthcare-Seeking Behavior in Women Aged 40-60 Years"and concluded that the prevalence of most symptoms, such as hot flushes/sweating, fatigue, and emotional disorder among the participants in the perimenopausal period was significantly 
higher than in the women in the pre- and postmenopausal periods.

This result is congruent with Ong et al., (2020) who studied "Experiences and Needs of Perimenopausal Women With Climacteric Symptoms in Singapore: A Qualitative Study" and found that more than half of the studied women complained of hot flushes, insomnia, mood changes, skin dryness, muscle and joint pain, vaginal dryness, and low sexual desire.

The result of the present study revealed that nearly one third of control and study groups complained of urinary incontinence and memory problems. Also there was no statistically significant difference among the studied groups regarding peri-menopause symptoms ( $>0.05)$.

In addition to that, this result is in agreement with Yisma, et al., (2017) who found that hot flush was the most prevalent somatic subscale symptom reported by perimenopausal women in $57.0 \%$ of cases, respectively. For psychological subscale symptoms, peri-menopausal women most commonly described depressive mood (36.4\%) symptoms. sexual problems $(15.2 \%)$ was the most prevalent urogenital symptom reported by peri-menopausal women .

Predisposing factors (knowledge, attitude, self-efficacy), reinforcing factors and enabling factors of the studied groups:

The study used PPM to enhance the lifestyle of peri-menopausal women, which was introduced as a successful model in many clinical and field trials (Azar et al., 2020). The present study clarifies that there was no statistically significant difference between control and study groups regarding predisposing, reinforcing, and enabling factors before PPM application $(p>0.05)$.
However, there was a highly statistically significant difference was observed in predisposing, reinforcing, and enabling factors of the study group compared with the control group after three and six months of PPM application ( $\mathrm{p}$ 0.001). This may be due to that the increase of the knowledge level and creation of a positive attitude was expressed as the effect of intervention based on the PPM on the behavior changes. This PPM helped women to establish good living habits which not only benefit peri-menopausal symptoms but also protect the perimenopausal women from chronic diseases in the future (Xi, et al., 2017).

This result is in agreement with Pourhaji, et al., (2020)who studied "Effects of educational program based on PrecedeProceed model in promoting low back pain behaviors in health care workers" and pointed out that the mean score of predisposing factors enabling, and reinforcing factors increased in intervention group $(\mathrm{p}<0.05, \mathrm{p}<$ 0.001 ), but no significant change in mean score of predisposing factors reinforcing factors, enabling factors in the control group $(\mathrm{P}>0.05)$.Also this result is in agreement with Khani et al., (2019) who revealed that before educational intervention, there were no significant differences between the two groups in predisposing factors, reinforcing factors, and enabling factors, however, 1 year after intervention, intervention group had significant enhancement in mentioned variables, whereas the control group had no changes.

\section{Lifestyle of the studied groups:}

Menopausal Transition-related problems can be aggravated by different factors, including unhealthy lifestyle habits, such as unhealthy eating, stressors, and limited physical activity (Sharifi et al., 2017). 
The present study shows that there was no statistically significant difference in the mean scores of the total health promoting lifestyle behaviors and its dimensions between the two groups before the intervention $(p>0.05)$. However, after three and six months of intervention, the mean difference scores for the total health promoting lifestyle behaviors and its dimensions in the study group was higher than the scores in the control group (p < $0.001)$. This may be due to that increasing awareness, creating positive attitude and having high self-efficacy are the effective steps to promote healthy behaviors and maintain the psychological wellbeing in perimenopausal women.

Taebi et al., (2018) added that educating women in different fields including introduction to peri-menopause and its problems, coping strategies, diet, body relaxation techniques, reinforcing factors and enabling factors have an important role in accepting menopause and enhancing lifestyle during this period.

This study is nearly congruent with Ali and Soliman (2018) who studied "Effect of Health Promoting Lifestyle Modifications on Quality of Life among Menopausal Women" and found that there were highly statistically significant differences between the two groups in the mean score of the "health-promoting lifestyle profile" before and after the intervention. Also, this study nearly agrees with Fujimoto, et al., (2017) who studied "Effectiveness of coaching for enhancing the health of menopausal Japanese women" and stated that health behavior goals were divided into five categories: Exercise, diet, stress management, life rhythm, and weight loss. Comparisons of top-priority goal achievement revealed significantly higher scores for the intervention group compared to the control group immediately postintervention $(\mathrm{t}=2.05, \mathrm{p}=.04)$.

Khani et al., (2019) revealed that there were no significant differences between the two groups regarding nutrition performance, and walking performance, however 1 year after intervention, intervention group had significant enhancement in mentioned variables, whereas the control group had no changes.

\section{Additionally Koçak and Beji (2019)} found that there was a statistically significant difference was observed in the pretest and posttest HPLP II scores and all the HPLP II sub-dimension scores of the menopausal women in the experimantal group. Also Malik, et al., (2018) made a study on "Health-Promoting Behaviors and Menopausal Symptoms" and found that result of independent $\mathrm{t}$-test revealed no significant difference between the groups with regard to mean health-promoting behavior score before intervention $(\mathrm{P}<0.05)$. The mean healthpromoting behavior score $(\mathrm{t}=8.7, \mathrm{P}=$ $\left.0.01^{* *}\right)$ was significantly high in the experimental group as compared to the comparison group at 0.05 level of significance.

As well as Asrami, et al.,(2016) conducted a study on "Health Promoting Lifestyle Behaviors in Menopausal Women" and pointed out that the results showed significantly higher scores of health promoting lifestyle behaviors between the two groups.

\section{Conclusion:}

The PPM provided an excellent framework for health intervention programs especially in enhancing lifestyle, and improved the understanding of the relationship between variables such as predisposing factors, reinforcing factors, enabling factors and lifestyle. 


\section{Recommendation:}

1. PPM must be applied in the process of education by considering all effective personal, environmental, and social factors to change the lifestyle of women.

2. Educational programs intended for women in the climacteric period must be extended about menopause, symptoms, long term consequences, and effective ways of dealing with it and such education should be supplemented with a educational manual or similar materials.

\section{References:}

Afshari, F., Bahri, N., Sajjadi, M., Mansoorian, M. R., \& Tohidinik, H. R. (2020). Menopause uncertainty: the impact of two educational interventions among women during menopausal transition and beyond,Przeglad menopauzalny = Menopause review, 19(1), 18-24.

Ali, A. A., and Soliman, E. E., (2018). Effect of Health Promoting Lifestyle Modifications on Quality of Life among Menopausal Women, Menoufia Nursing Journal, 1(3):112.

Asrami, F. S., Hamzehgardeshi, Z., and Shahhosseini, Z. (2016). Health Promoting Lifestyle Behaviors in Menopausal Women: A Cross-Sectional Study, Global journal of health science, 8(8):128-134.

Azar, F. E., Solhi, M., Darabi, F., Rohban, A., Abolfathi, M., and Nejhaddadgar, N. (2018). Effect of educational intervention based on PRECEDE-PROCEED model combined with self-management theory on self-care behaviors in type 2 diabetic patients.
Diabetes \& Metabolic Syndrome: Clinical Research \& Reviews,12(6): 1075-1078.

Bae, J., Park, S. and Kwon, J.W., (2018). Factors associated with menstrual cycle irregularity and menopause, BMC Women's Health, 18 (36):1-11.

Bammann, K., Recke, C., Albrecht, B. M., Stalling, I., and Doerwald, F. (2020). Promoting Physical Activity Among Older Adults Using Community-Based Participatory Research With an Adapted PRECEDE-PROCEED Model Approach: The AEQUIPA/OUTDOOR ACTIVE Project. American Journal of Health Promotion, 089011712097487.

Delamater L., and Santoro N., (2018). Management of the Perimenopause, : Clinical Obstetrics and Gynecology, Wolters Kluwer Health, Inc., 61(3),PP.,419-432.

Du, L., Xu, B., Huang, C., Zhu, L., and He, N. (2020). Menopausal Symptoms and Perimenopausal Healthcare-Seeking Behavior in Women Aged 40-60 Years: A CommunityBased Cross-Sectional Survey in Shanghai, China. International Journal of Environmental Research and Public Health, 17(8), 2640.

Ebrahimi, M., and Rahimi, B., (2019). The effect of self-efficacy counseling on the management of menopausal symptoms in psychological dimension in perimenopause women referred to health centers in Mahabad city. J Adv Pharm Edu Res 2019;9(S2):93-97. Source

Falkingham, J., Evandrou, M., Qin, M., and Vlachantoni, A., (2020). Chinese women's health and wellbeing in middle life: Unpacking the influence of menopause, 
lifestyle activities and social participation, Maturitas, 143, 145-150.

Faraji K, Kamrani M.A, Saeieh S., and Farid M.,(2018). Could a Midwife Leading Health Behavior Counseling Improve SelfCare of Women During Perimenopause? A Quasi-Experimental Study, J Midlife Health, 9(4):195-199.

Farland, L.V., Mu, F., Eliassen, A.H. et al., (2017). Menstrual cycle characteristics and steroid hormone, prolactin, and growth factor levels in premenopausal women. Cancer Causes Control 28, 1441-1452 (2017).

Fujimoto, K. ,(2017). Effectiveness of coaching for enhancing the health of menopausal Japanese women, Journal of Women \& Aging, 29(3): 216-229 .

Ghaderi, E, Ghazanfarpour, M, Kaviani, M. (2010).Evaluation of menopausal women's attitudes towards menopause in Shiraz. Pak, J Med Sci .,26(3): 698-703.

Huang, Z., Shi, J., Liu, W., Wei, S., and Zhang, Z. (2020). The influence of educational level in peri-menopause syndrome and quality of life among Chinese women. Gynecological Endocrinology, 1-6

Khandelwal, S., (2020). Obesity in midlife: lifestyle and dietary strategies. Climacteric, 23(2): 1-8.

Khani J. A., Ghasemi, M., Hossein, A.M., Jamshidi, H., and Afzali, P.H., (2019). The Application of PRECEDE Model on Preventing Osteoporosis in Women, Clinical Nursing Research :1-24.

Koçak Y., and Beji K.,(2019). Effect of Health Promoting Lifestyle Education Program on reducing the menopausal symptoms of women in Turkey, Cukurova Medical Journal Cukurova Med J, 44(3):850860.

Li, J., Yu, J., Chen, X., Quan, X., and Zhou, L. (2018). Correlations between health-promoting lifestyle and health-related quality of life among elderly people with hypertension in Hengyang, Hunan, China. Medicine, 97(25), e10937.

Malik, E., Sheoran, P., and Siddiqui, A., (2018). Health-Promoting Behaviors and Menopausal Symptoms: An Interventional Study in Rural India, Journal of mid-life health, 9(4), 200-206.

Marshall, S., and Rees, M. (2020). Managing menopause and post-reproductivehealth with nutrition and lifestyle, Nutrition and Dietetics, 77(S1), 63: [18].

Moshki M., Mohammadzadeh F., and Dehnoalian A., (2017). The effectiveness of a group-based educational program on the selfefficacy and self-acceptance of menopausal women: A randomized controlled trial, Journal of Women \& Aging, 30(4):310-325.

Narjes B., Nooshin Y., Mohammad A. M., Delshad N. A., Moosa S., (2020). the effects of menopausal health training for spouses on women's quality of life during menopause transitional period, 23 (2) :183188.

Ong, D. S. P., Chua, M. T., and Shorey, S. (2020). Experiences and Needs of Perimenopausal Women With Climacteric Symptoms in Singapore: A Qualitative Study, Journal of Transcultural Nursing, 31(4):1-9.

Panay, N., Briggs‘ P., and T. Kovacs G., (2020). Managing the Menopause, $2^{\text {nd }}$ 
edition, Cambridge University Press, PP., 254-264.

Pourhaji, F., Delshad, M. H., Tavafian, S. S., Niknami, S., and Pourhaji, F. (2020). Effects of educational program based on Precede-Proceed model in promoting low back pain behaviors (EPPLBP) in health care workers Shahid Beheshti University of medical sciences: randomized trial, Heliyon, 6(10), e05236.

Rabiee, N., Karimi, F., Motaghi, Z., (2019). Effect of lifestyle on psychological wellbeing and severity of menopausal symptoms in women during the premenopausal period, International journal of health studies ,5(3):33-37.

Reece S. M., and Harkless E. G., (2002). Testing of the PHS-ES: A Measure of Perimenopausal Health Self-Efficacy, 10(1):15-26.

Royal College of Nursing (2019). Nurse specialist in menopause: online resources https://www.rcn.org.uk/-/media/royalcollege-of-nursing /documents /publications/2019/july/007-732.pdf?la=en.

Sharifi,F., Moodi, M., Sharifzade, G., and Malaki Moghadam, H.,(2017). The Effects of an Educational Intervention Based on the Health Belief Model and Self-Regulation on Women's Eating Behaviors During Menopausal Transition, Mod Care J. 2017 ; 14(2):e65305.

Sis Çelik, A., and Pasinlioğlu, T. (2019).Effects of imparting planned health education on hot flush beliefs and quality of life of climacteric women, Climacteric, 20(1), 25-30.
Taebi, M., Abdolahian, S., Ozgoli, G., Ebadi, A., \& Kariman,N.,(2018).Strategies to improve menopausal quality of life: A systematic review, Journal of education and health promotion, $7,93$.

Walker, S.N, Sechrist, K. R, Pender, N. J., (1987). The Health-Promoting Lifestyle Profile: development and psychometric characteristics, Nurse Res., 36(2):76-81.

Willi J., Süss H., Grub J., and Ehlert U., (2020). Prior depression affects the experience of the perimenopause - findings from the Swiss Perimenopause Study, Journal of Affective Disorders, 277:603-611.

World Health Organization (2018). Report of a WHO Scientific Group: Research on the Menopause. Geneva: World Health Organization, WHO Technical Report Series.

Yisma E., Eshetu N., , Ly S., and Dessalegn B., (2017). Prevalence and severity of menopause symptoms among perimenopausal and postmenopausal women aged 30-49 years in Gulele sub-city of Addis Ababa, Ethiopia, BMC Women's Health ,17:124. 
تأثير برنامج تعليمي على نمط حياة السيدات اللاتي في مرحلة ما حول سن الإياس باستخدام نموذج بريسيد بروسيد

$$
\text { جهاد جمال السيد - محرم عبدالحسيب- سعاد عبدالسلام - سماح عبدالحليم }
$$

تعد مرحلة منتصف العمر مرحلة فريدة من نوعها في حياة كل السيدات لأنها نشير الي بداية الطريق الي انهاء الحياة الانجابية ـ لذلك هدفت هذه الدر اسة إلى تحليل تأثثر برنامج تعليمي على نمط حباة السيدات اللاتي في مرحلة ما حول سن الإياس باستخدام نموذج بريسيد بروسيد. وقد أجريت الدراسة في قسم النسا والتوليد في مستشفى بنها الجامعى على مجمو عتين (00 سيده في فترة ماحول سن الاياس تلقين البرنامج التعليمي باستخدام نموذج برسيد بروسيد والمجموعة الضابطة تضم ؟ه سيدة في فترة ما حول سن الاياس لم يتلقين البرنامج التعليمي). حيث كثفت النتائج عن ان نموذج بريسيد بروسيد قدم هيكلا ممتاز اللبر امج المتخصصة في تحسين وتعزيز الصحة بسبب التطور الكبير الذي لوحظ في مكونات مرحلة التقييم التعليمي والبيئة ونمط الحياة المعزز للصحة لمجمو عة الدر اسة بعد تطبيث البرنامج مقارنة بالمجموعة الضابطة . كما أوصت الدراسة بتنفيذ برامج تعليمية للسيدات اللاتي في هذه المرحلة الانتقالية عن فترة ما بعد سن الاياس و المضاعفات و الطرق الفعالة للتكيف. 